\title{
Ethiopia: Ugly Mathematical Unit Cost Fiscal Equalization Formula; Beautiful Findings
}

\author{
Dr. Ludovick Leon Shirima \\ Department of Business, Higher Colleges of Technology, Abu Dhabi Men's College, Abu Dhabi, UAE \\ *Correspondence: Dr. Ludovick Leon Shirima, Email: 1leon@linuxmail.org
}

\begin{abstract}
Purpose: Grant allocation formulas used to allocate fiscal resources among different tiers of government have proved to be useful in many countries around the world. This article provides a unit cost approach equalization formula that was used in the Federal Democratic Republic of Ethiopia (FDRE) to transfer resources from the regions to the woredas (districts) in 2007.

Study methodology: The study approach involved gathering and reviewing of pioneering literature; identifying six representative sectors; field visits to collect and collate data; and data analysis.

Findings: The developed model was highly equalizing. The FDRE adopted the study recommendations and the regional governments used the formula, or a modified version thereof, to transfers resources to woredas.

Research limitations: It was not easy to access the required data. Furthermore, the representative sectors may not holistically reflect the actual budgetary needs of the Local Governments (LGs) due to their heterogeneous tax bases and expenditure needs. This can be addressed with future research to further refine the model presented and granularity of data used.

Practical implications: The study developed and specified a mathematical unit cost equalization model, which was applied to Tigray region in FDRE. The model's ability to equalize was tested and evaluated econometrically.

Social implications: The paper identified six representative sectors that have high synergies in terms of poverty eradication via improved social service delivery. These sectors attracted large budgetary allocations.
\end{abstract}

Keywords: Equalization formula, Intergovernmental, Fiscal decentralization, Expenditure needs, Revenue capacity, Ethiopia

\section{ARTICLE INFORMATION}

Author(s): Dr. Ludovick Leon Shirima

Received: 04 Dec, 2020; Accepted: 09 Feb, 2021; Published: 05 Mar, 2021;

e-ISSN: 2347-4696;

Paper Id: BMN-IJBMR-2020-20;

Citation: doi.org/10.37391/IJBMR.090109

Webpage-link:

https:/ijbmr.forexjournal.co.in/archive/volume-9/ijbmr-090109.html

\section{INTRODUCTION}

This article investigates intergovernmental fiscal relations for the Federal Democratic Republic of Ethiopia (FDRE). Administratively, FDRE has nine regional governments and two towns. ${ }^{1}$ The article builds on earlier work commissioned by the District Level Decentralization Programme (DLDP). ${ }^{2}$ DLDP dichotomized the sub-national-level governments (SNLGs) into reforming and less-developed regions. The grouping was based on the level of economic advancement and the region's ability to amass fiscal and financial data for planning and budgeting purposes. The current article focuses on the former.

Following the successful completion of the advisory services and sound recommendations, the FDRE adopted them all. The objective of this study was to develop an intergovernmental grant transfer formula to allocate funds from the Regional

${ }^{1}$ These included nine regions of Afar, Benshangul Gamuz, Gambela, Tigray, Southern Nations, Nationalities and

${ }^{2}$ This article originated from the author's work as a Senior Fiscal Decentralization Advisor under the DLDP, managed by the Ministry of Capacity Building of the FDRE.

Website: www.ijbmr.forexjournal.co.in states to the Woreda-level sub-national governments. The study used data and mathematical formulations to design a robust model for allocation. It also benefitted from numerous technical reviews from development partners and stakeholders supporting the decentralization programmes in the FDRE, including the World Bank; USAID; and Ministries, Departments, and Agencies (MDAs). The purpose of this article is to share experiences and insights for developing a pragmatic grant equalization formula.

The paper is organised into seven main sections: Section 1 is the present introductory context; Section 2 examines the methodology employed for the study; Section 3 explains the data (including sources) used; Section 4 reviews the formula design and model specifications; Section 5 discusses an ugly mathematical unit cost approach to the equalization formula; Section 6 provides model simulation using data from Tigray region; and Section 7 details recommendations and conclusions.

\section{STUDY METHODOLOGY}

The methodology employed by this study included a review of pertinent literature and field visits to regions, towns, and Woredas for consultations. The study carried out data collection, collation, and analysis to develop informed policy recommendations based on tangible figures.

\subsection{Desk Review of Literature and Related Documents}

The study reviewed a multitude of studies on intergovernmental fiscal relations and grant formulas for 
Ethiopia with specific attention to regional formulae design approach. Comparable international best practice studies were also examined to build a strong comprehension of the theoretical and empirical aspects required for the analysis.

\subsection{Field Visits to Regions and Woredas}

The author visited all nine regions and the two towns, including a few of their respective woredas. Ex ante, a set of questionnaires were developed, tested, and sent to the regions, towns, and woreda bureaus prior to the actual visits. The purpose of the field visits was to investigate the types of equalization formulas used in each region and to collect primary and secondary data on their fiscal performance and position. A checklist of documents and data requirements were developed and structured interviews were organised.

The interviews were of different types, such as round-table discussions and consultations. The attendees came from all levels of government, ${ }^{3}$ including Bureaus of Capacity Building (BCB), DLDP, Bureau of Finance and Economic Development (BOFED), and Woreda Office of Finance and Economic Development (WOFED). Officials from these bureaus provided feedback voluntarily and shared concerns about the transfer practices within their respective jurisdictions. The findings and feedback from both interviews and consultations were subsequently summarised; this proved to be useful for later analysis.

\subsection{Data Collection, Collation, and Analysis}

The study amassed a large volume of secondary data on population, land area, fiscal performance, and position of the SNLGs, as expounded elsewhere in this paper. This was subsequently expanded to include socio-economic and macroeconomic parameters. The data was cleaned and combined to develop a portable working dataset; this was used for analysis, tabular presentation of findings, and interpretation of results.

The author held a series of seminars and workshops to validate the output of the data analysis. The study concluded by developing a prototype formula for transfer of resources from regions to woreda-level governments. In the section that follows, the paper provides a detailed account of data issues and sources.

\section{DATA ISSUES AND SOURCES}

Data used in this study originated from various sources. One, the Ethiopian Ministry of Finance and Economic Development (MOFED) provided statistics on central government revenues ${ }^{4}$, external funding, and transfers to regional states. Two, statistics on local government revenues and expenditures came from the regional BOFED and WOFED. These included all revenues assigned to the SNLGs, as devolved by the

\footnotetext{
3 These levels constituted the three tiers of government, namely federal, regional, and woreda (district) in the FDRE.

${ }^{4}$ Revenues included major taxes, such as the personal income tax, corporate income tax, value added tax (VAT), excise duties, and customs duties.
}

constitution. ${ }^{5}$ Three, data on Household Living Conditions came from the Poverty Monitoring Unit, based on the 2000 and 2004 Ethiopian National Household Surveys. This contains microeconomic information on district poverty rates. Lastly, macroeconomic and socio-economic data came from the Central Statistical Authority, Central Bank of Ethiopia, the International Monetary Fund (IMF), and the World Bank. This included population census per district, GDP at current prices, land areas (for regions, towns, and woredas), revenue, budget figures, and consumer price indices.

\section{ASPECTS OF GRANT FORMULA DESIGN}

Designing a good transfer system involves three main considerations: transfer pool determination, formula architecture, and political dimensions of the grant (Bird and Smart, 2002). We examine the first two considerations in turn below.

\subsection{Transfer Pool Determination}

Firstly, a good transfer system depends on the methodology for determining the transfer pool. ${ }^{6}$ Key attributes include predictability, flexibility, and stability. As discussed by several studies [1] and supported by empirical evidences, there are three traditional ways of determining the transfer pool applicable in any country.

(i) As a fixed proportion of central government revenues. This methodology, for instance, has been applied successfully in Rwanda [2]. In the Philippines, the transfer pool is a function of the pre-determined share of national taxes [3]. In the developed countries of Austria and Japan, ${ }^{7}$ the same is applied, where 12 percent of income tax and value added tax (VAT) in the former and 32 percent of income and alcohol taxes of the latter are respectively transferred to their local governments. The large, emerging federal countries of Nigeria and Brazil also use such systems [4].

(ii) On an ad-hoc basis; that is, in the same way as any other budgetary expenditure. This was the approach used by FDRE's MOFED since transfer allocation started in 1995/96 and was inherited by the regional state governments in distributing grants to the woredas.

(iii) On a formula-driven basis, in which reimbursements of a proportion of specific local expenditures by the central government are related to some general characteristic of the recipient jurisdiction.

Empirical evidence shows that option (i) is the most preferred approach by the lower levels of government because it ensures transparency, predictability, and stability $[1,6]$. However,

\footnotetext{
${ }^{5}$ Interested readers should consult the FDRE Constitution.

6 In literature, transfer pool is synonymous or also known as distributable pool or primary distribution or the financial envelope.

7 See, for instance, Fujiwara [5] and Yonehara (1993) for an elaborative discussion.
} 
option (iii) seems to be favoured by most central governments because the determination is in accordance with budgetary priorities; hence, the central government can maintain maximum political and budgetary control.

In practice, transfers to the SNLGs from higher levels in FDRE ensures that at least the lower level receives block grants that are nominally higher than the previous year's entitlement. Our analysis shows that this forms about 40 percent of their own source revenues (OSRs) and that of the federal transfers received. The OSRs of many SNLGs are numerous and heterogeneous from one to another.

\subsection{Grant Transfer Formula Architectural Design}

Secondly, a transfer system allocates grants based on a formula of some sort. This section surveys and summarizes approaches adopted in several developed countries, as well as developing countries, to gain the necessary exposure of the relevant issues and is then used to construct a model applicable for FDRE. There are four common options for determining the intergovernmental fiscal transfer formula; these are discussed further below.

The first category includes formulae that equalize revenue capacities, as is utilized in Canada. Critics of the model-for instance, Broadway and Hobson [7]-cited various reasons, including, but not limited to: (a) weak data requirements; (b) it applies a representative tax system that is difficult to ascertain at the onset; and (c) it ignores the large differences in special expenditure needs across regions. In addition, Smart [8] criticizes this by arguing that it may drive local tax rates higher than is desirable, from a national point of view. However, it is commendable for its simplicity and it is less demanding in terms of data requirements.

The second category includes formulae that allocate grant transfers based on some need indicators; this approach is applied, for instance, in India, Italy, and Spain. It ignores information on revenue capacity; this can potentially be attributed to the difficulty in finding this kind of data in both developed, as well as developing, countries.

The third category includes formulae that distribute equalization grants on a per-capita basis in an attempt to equalize the actual spending of local governments [9]. This type of formula is typically used to allocate specific purpose grants. ${ }^{8}$ Germany uses it to distribute resources from its Value Added Tax (VAT) sharing mechanism; Canada uses it to allocate an earmarked grant, known as the Established Programs Financing (EPF); in England, it is used to disburse Non-Domestic Rating (NDR) tied grants; and in Indonesia it

\footnotetext{
8 Several studies identified four types of grants applicable in a country as a single, whole, or composite mix of the various grants; namely, these include: conditional grants, unconditional grants, matching grants, and equalization grants [13, 14].
}

has been applied for the famous Instruksi Presiden (INPRES) ${ }^{9}$ special purpose grant. It is one of the simplest types of formulas and its data requirements are very limited. Nevertheless, several authors criticize this approach for its inability to achieve equalization with changes over time [6].

Finally, the fourth category consists of formulae that equalize both the revenue capacity and expenditure needs of different SNLGs. This model is widely used in developed countries because they are well-equipped, in terms of data availability. Australia has long applied this approach. Interested readers should consult the following studies for more insights: Musgrave [10] and Richard and Searle [11] for Australia; Baretti, Huber, and Lichtblau [9] for Germany; and Jun for Japan and Korea.

\subsection{Application of Equalizing Revenue Capacity and Expenditure Needs Model}

This paper applies the latter option, which equalizes both revenue capacity and expenditure needs. Theoretically, countries attempt to ensure that revenues and expenditures of each level of government are equivalent [12]. We begin by illustrating how to construct the formula.

Modeling this mathematically, it takes the form:

$\mathrm{T}_{i}=\left(\mathrm{N}_{i}-\mathfrak{R}_{i}\right)-\Gamma_{i}$

Where,

$\mathrm{P}=$ the total transfer pool,

$\mathrm{T}_{i}=$ transfer to the ith woreda,

$\mathrm{N}_{i}=$ expenditure needs for the ith woreda,

$\mathfrak{R}_{i}=$ revenue capacity for the ith woreda, and

$\Gamma_{i}=$ other transfers to the ith woreda (e.g. specific grants).

Hence, by summing all the woredas' transfers in one region and relating it to the total transfer pool available, we can write: $\sum_{i} \mathrm{~T}_{i}=\mathrm{T}=\mathrm{P}$

Where $\mathrm{T}=$ Denotes all total woreda transfers for a given region.

The above equation represents the funding required for all woredas in a given region.

An individual woreda then on average receives:

$\overline{\mathrm{T}}=\frac{\mathrm{P}}{n}$

Where $n$ stands for the total number of woredas in that region.

Considering the fiscal gap of each woreda in a single region, we can write:

$\mathfrak{I}_{i}=\left(\mathrm{N}_{i}-\mathfrak{R}_{i}\right)$

Where $\mathfrak{I}_{i}=$ woreda $i^{\text {th }}$ fiscal gap.

\footnotetext{
9 See, for instance, Bambang and Jorge Martinez [15] for more discussion on INPRES.
} 
Summing all woredas' fiscal gaps we obtain the regional state fiscal gap, which can write as:

$$
\mathfrak{I}=\sum_{i} \mathfrak{I}_{i}=\left(\mathrm{N}_{i}-\mathfrak{R}_{i}\right)
$$

Where $\mathfrak{I}=$ the regional state fiscal gap.

In the literature, studies offer several methods to bridge this fiscal gap. Central governments might, for example, transfer revenue-raising powers to SNLGs, transfer expenditure responsibilities to the centre, reduce local expenditures, or raise local revenues $[7,16,17]$. FDRE adopted a combination of these measures.

\subsection{Architectural Design of the Revenue Capacity Side of the Formula}

Measuring revenue capacity has never been an easy task. It is the ability of the government to raise revenues from its OSRs and revenue-sharing arrangements [18]. The methodology is often used to measure revenue capacities in developing countries and involves the use of data on major tax bases and standard (average) tax rates. ${ }^{10}$ The idea is to estimate revenue capacity of a region by approximating the revenue that the region could raise if its government taxes all the standard tax bases with the standard tax effort. ${ }^{11}$ There are a series of proposed steps for estimating revenue capacity:

One: Start by specifying your model equations clearly and defining the parameters used in a simple manner.

Hence, the revenue capacity could be mathematically modeled as:

$\mathfrak{R}_{i}=\sum_{j} \beta_{i j} * \tau_{j}$

Where,

$\beta_{i j}=$ the $i^{\text {th }}$ Woreda's $\mathrm{j}^{\text {th }}$ tax base; and

$\tau_{j}=$ the standard (e.g. regional/national average effective) tax rate on the $j^{\text {th }}$ tax base.

Two: Identify the appropriate tax bases. It is not easy to include all tax bases available, since collecting data on small tax bases may be very costly. Therefore, it is advisable to rely on the major tax base available for the region. In FDRE, it seemed plausible to use taxes on 'land use' and non-taxes to approximate woreda revenue capacities.

Three: Collect detailed information on the identified tax bases. This involves, for example, collecting historical data for the selected revenue sources or obtaining an average of several years. In the case, where data is provided directly from the woreda administration, it is important to ensure there is no

\footnotetext{
${ }^{10}$ For instance if the tax base is income tax then the average tax rate is the percent of taxes divided by taxable income, i.e. the average tax rate equals total taxes divided by total taxable income. Calculating the average tax rate involves adding all of the taxes paid under each bracket and dividing it by total income.

${ }^{11}$ Tax effort is the index of the ratio between the share of actual tax collection to GDP and taxable capacity
}

misreporting. A government administration can impose strict compliance rules that are punishable or involve fines for any false reporting. Data manipulation can result in transfers being largely a proxy controlled by the SNLG's own tax effort. China and Indonesia used the approach years back, despite the demerits cited. This study proposes a use of mean revenue of tax and non-tax collected over the past few years, depending on data availability.

Four: Notwithstanding the above, select the standard tax rates. Numerous approaches could be applied to establish a standard tax rate. Some countries, such as Indonesia, apply effective tax rates $^{12}$ for the whole country. Others use the arithmetic mean of all regions' or districts' effective tax rates; lastly, some apply the arithmetic mean of few selected regions' or districts' effective tax rates. This study used the latter approach.

Five: Implement the calculations via equation (6) specified above.

\subsection{Architectural Design of the Unit Cost Approach to Estimating Expenditure Needs}

The current study adopted the unit cost approach to imputing the expenditure needs of a given SNLG applied in the United Kingdom (UK), Australia, Japan, and Korea. The approach involves disaggregating the total expenditures of a SNLG, according to its different sectors; then, estimating their respective needs. After summing up the estimated sectors' expenditure needs, one arrives at the total expenditure needs for a given SNLG.

The study identified six sectors, namely education, health, agriculture, water, roads, and government administration (administration and general services). The section that follows sequentially lays out the steps involved in deriving each sectors' expenditure needs via unit costs. It further expounds the proxies considered.

One: Determine the share of each sector's expenditure needs as part of the total expenditure.

Using one-period lagged data on actual expenditure, establish each sector's share as a proportion of total recurrent and capital budgets.

Mathematically, let:

$\mathrm{N}=$ the total woreda actual expenditure needs in all six sectors; and

$\alpha_{k}=$ Sector $q^{\text {th }}$ 's share as a proportion of total expenditures Change the $\mathrm{k}$ into $\mathrm{q}$

Where,

$q=1, \ldots \ldots .6$, representing the 6 sectors identified above.

Hence,

$$
\mathrm{N}_{q}=\alpha_{q} \mathrm{~N}
$$

${ }^{12}$ It is calculated by dividing total taxes paid by the total taxable base. 
Where,

$\mathrm{N}_{q}=$ denotes the total expenditure needs of the $q^{\text {th }}$ sector.

Two: Introduce the unit cost approach to calculate the expenditure needs of each sector.

Let:

$\mathrm{N}_{q i}=\bigcup_{q i} * \bar{\pi}_{i} * \sigma_{i}$

Where:

$\mathrm{N}_{q i}=$ expenditure needs in the $q^{\text {th }}$ sector for the $i^{\text {th }}$ woreda;

$\cup_{q i}=$ the unit of measurement; that is, the number of units

that receive services in sector $q$ from the $i^{\text {th }}$ woreda government;

$\bar{\pi}_{i}=$ average per unit cost for the $i^{t h}$ woreda government expenditure needs; and

$\sigma_{i}=$ Adjustment coefficient for the $i^{\text {th }}$ Woreda government.

Mathematically, this takes the form:

$\bar{\pi}_{i}=\frac{\mathrm{N}_{q i}}{U_{q i}}$

The adjustment coefficient is a combination of factors that differentiate the unit cost of the services in the specific woreda from the regional or national average.

Three: Calculate the expenditure needs for the woreda government in sector.

Four: Sum up all these sectors' expenditure to arrive at the woreda's total expenditures.

Theoretically, the model aims to simultaneously control the two parameters that determine the fiscal gap (i.e., to minimize the fiscal gap).

\section{THE UGLY UNIT COST} MATHEMATICS OF ESTIMATING EXPENDITURE NEEDS

This article adopted sectoral analysis and focused only on six sectors that have high synergy for poverty reduction. The proposed approach minimizes the number of proxies, combining the various indices multiplicatively and not additively, and revises the definition of the unit cost and its imputation by introducing plausible adjustment or "disability" factors. The study also introduces a new proxy capturing revenue capacity, which was missing from the previous models. That is, the revenue effort proxy that aimed at reflecting the ability of SNLGs to generate revenues and intended to reward the high-effort regions in terms of revenue collection was substantially improved.

The proposed model sought to equalize revenue capacity, as well as expenditure needs; therefore, minimizing, and, over time, eliminating the fiscal gaps. The study tested and compared the proposed model to the existing versions by using data from Tigray regional state to confirm that it was statistically equalizing. The suggested system was more systematic because it harmonized capital budgeting grants and considered the variations between rural and urban administration localities.

It involved two stages in estimating the dual components of the formula; namely, revenue capacities and expenditure needs analogous to the prescribed model above. Therefore, the transfer model proposed closely follows the Australian model mentioned earlier. First, we estimated revenue capacity using the approach suggested in Equation (6) above. The current section specifies unit cost equations used in the imputation of the expenditure needs for the woreda in sector. They assume different forms, as shown hereunder.

(i) Calculate the expenditure need for education $\operatorname{sector}^{(q=\mathrm{E})}$ of the $i^{i t h}$ woreda

The study used the number of school-aged children and the number of teachers to capture information about the education sector. The number of school-aged children was a proxy and the number of teachers was a disability factor. The proportion of the woreda cost of living to the regional level was useful to adjust for prices and scale up the results. It entered the model inversely, as depicted in the mathematical formulation. ${ }^{13}$

Let $\mathrm{N}_{E i}$ denote expenditure needs in the education sector for the $i^{\text {th }}$ woreda, and write:

$\mathrm{N}_{E i}=\left(\frac{\mathrm{N}_{E}}{\bigcup_{E}}\right) * \bigcup_{E i} * \delta\left(\frac{\varepsilon_{i}}{\varepsilon} / \frac{\mathrm{P}_{i}}{\mathrm{P}}\right) *\left(1 / \frac{\theta_{i}}{\theta}\right)$

Using Equation (8) above, it can be written as:

$\mathrm{N}_{E i}=\alpha_{E}\left(\mathrm{~N} / \bigcup_{E}\right) * \bigcup_{E i} * \delta\left(\frac{\varepsilon_{i}}{\varepsilon} / \frac{\mathrm{P}_{i}}{\mathrm{P}}\right) *\left(1 / \frac{\theta_{i}}{\theta}\right)$

Where,

$\mathrm{N}_{E}=$ the regional state total expenditure needs for education;

$U_{E}=$ the school age population in the regional state;

$\cup_{E i}=$ the school age population in the $i^{\text {th }}$ woreda;

$\delta=$ adjustment coefficient ${ }^{14}$ to discount the magnitude of the unit cost $\left(\frac{\mathrm{N}_{E}}{\mathrm{U}_{E}}\right)$ demanded by the respective parameter;

$\varepsilon_{i}=$ the number of teachers in the $i^{\text {th }}$ woreda;

$\varepsilon=$ the number of teachers in the respective regional state government;

$\theta_{i}=$ the cost of living in the $i^{\text {th }}$ woreda; and

$\theta=$ the cost of living in the respective region.

${ }^{13}$ This formulation was used in all six sectors for the same statistical role.

${ }^{14}$ It is advisable to determine this by regression, as evidenced by Equation 12. 
To determine the adjustment factor $\delta$, the study applied OLS regression where educational share was regressed against the student-teacher ratio.

The results were:

$\alpha_{\mathrm{Ei}}=0.039+0.997 \mathrm{STR}_{\mathrm{i}}$

$$
\text { (0.027) (0.000) }
$$

The results were statistically significant with adjusted RSquared of 0.994 . The number of observations was 45 , with 44 degrees of freedom. Since the derived coefficient was very close to 1 , we did not substitute it in our equation; we decided to omit it (that is, $\delta=0.997 \cong 1$ ). Then, we substituted this in Equation (10) above.

(ii) Calculate the expenditure need for the health $\operatorname{sector}(q=\mathrm{H})$

Equation (12) combined the following variables to estimate the expenditure needs for the sector. They included population as a proxy for beneficiaries, while health sector workers represented a disability factor.

Let $\mathrm{N}_{H i}$ denote the expenditure need in the health sector for the $i^{\text {th }}$ woreda, and write:

$\mathrm{N}_{H i}=\left[\left(\left(\frac{\mathrm{N}_{H}}{\mathrm{U}_{H}}\right) * \mathrm{U}_{H i}\right) /\left(\frac{P_{i}}{P}\right)\right] *\left(1 / \frac{\theta_{i}}{\theta}\right)$

Using Equation (8) above, it can be written as: Check the asterisk

$\mathrm{N}_{H i}=\left[\left(\left(\frac{\alpha_{H} \mathrm{~N} *}{\bigcup_{H}}\right) * \bigcup_{H i}\right) /\left(\frac{\mathrm{M}_{i}}{\mathrm{M}}\right)\right] *\left(1 / \frac{\theta_{i}}{\theta}\right)$

Where,

$\mathrm{N}_{H}=$ regional state total expenditure needs for the health sector;

$U_{E}=$ the total population of beneficiaries in the respective regional state;

$\bigcup_{H i}=$ the total population in the $i^{\text {th }}$ woreda;

$M_{i}=$ the total number of health workers in the $i^{\text {th }}$ woreda; consider the use of $\mathrm{H}, \mathrm{i}$, and $\mathrm{j}$;

$M=$ the total number of health workers in the respective regional state government; and all other notations as defined earlier.

(iii) Calculate the expenditure need for the agricultural $\operatorname{sector}(q=\mathrm{A})$

In the agricultural sector, we used three variables; namely, total population as a proxy and the number of livestock and farming households as disability factors.

Let $\mathrm{N}_{A i}$ denote the expenditure need in the agricultural sector for the $i^{\text {th }}$ woreda, and write:
$\mathrm{N}_{A i}=\left[\left(\frac{\mathrm{N}_{A}}{\mathrm{U}_{A}}\right) * \mathrm{U}_{A i} *\left(\left(1 / \frac{L_{i}}{L}\right)+\left(1 / \frac{\prod_{i}}{\Pi}\right)\right) *\left(\frac{\mathrm{P}_{i}}{\mathrm{P}}\right)\right] *\left(1 / \frac{\theta_{i}}{\theta}\right)$

Using Equation (8) above, it can be written as:

$\mathrm{N}_{A i}=\left[\alpha_{A} \frac{\mathrm{N}}{\mathrm{U}_{A}} * \mathrm{U}_{A i}\left(\left(1 / \frac{L_{i}}{L}\right)+\left(1 / \frac{\Pi_{i}}{\Pi}\right)\right) *\left(\frac{\mathrm{P}_{i}}{\mathrm{P}}\right)\right] *\left(1 / \frac{\theta_{i}}{\theta}\right)$

Where,

$\mathrm{N}_{A}=$ regional state total expenditure needs for the agricultural sector;

$\cup_{A}=$ the total population of livestock and farming households in the respective regional state;

$\bigcup_{A i}=$ the total of number livestock and farming households in the woreda;

$\Pi_{i}=$ the number of farming households in the $i^{\text {th }}$ woreda;

$\Pi=$ the number of farming households in the respective regional state government;

$L_{i}=$ the number of livestock in the $i^{\text {th }}$ woreda;

$L=$ the number of livestock in the respective regional state government;

$\mathrm{P}_{i}=$ the population of the $i^{\text {th }}$ woreda; and

$\mathrm{P}=$ the total population of the region.

(iv) Calculate the expenditure needed for the water sector $(q=W)$

Clean water services play a crucial role to the lives of people in any society. Therefore, the total population was a proxy, and the population served with clean water and land area was disability factors.

Let $\mathrm{N}_{W i}$ denote the expenditure needs in the water sector for the $i^{\text {th }}$ woreda, and write:

$\mathrm{N}_{W i}=\left(\frac{\mathrm{N}_{W}}{\mathrm{P}}\right) * \mathrm{P}_{i} *\left(\frac{\rho_{i}}{\rho}\right) *\left(1 / \frac{\theta_{i}}{\theta}\right)$

Using Equation (8) above, it can be written as:

$\mathrm{N}_{W i}=\left(\frac{\alpha_{W} \mathrm{~N}}{\mathrm{P}_{W}}\right) * \mathrm{P}_{W i} *\left(\frac{\rho_{i}}{\rho}\right) *\left(1 / \frac{\theta_{i}}{\theta}\right)$

Where,

$\mathrm{N}_{W}=$ regional state total expenditure needs for the water sector;

$\rho_{i}=$ the total population served with clean water in the

$i^{\text {th }}$ woreda; and

$\rho=$ the total population served with clean water in the regional state.

(v) Calculate the expenditure need for the road sector $(q=R)$

We selected two variables; namely, the population as a proxy and the land area as a disability factor. 
Let $\mathrm{N}_{R i}$ denote the expenditure needed in the road sector for the $i^{\text {th }}$ woreda, and write:

$$
\begin{aligned}
& \mathrm{N}_{R i}=\left(\left(\frac{\mathrm{N}_{R}}{\mathrm{P}}\right) * \mathrm{P}_{i} *\left(\frac{\mathrm{P}}{\mathrm{A}} / \frac{\mathrm{P}_{i}}{\mathrm{~A}_{i}}\right)\right) * 1 / \frac{\theta_{i}}{\theta} \\
& \mathrm{N}_{R i}=\left(\left(\frac{\alpha_{R} \mathrm{~N}}{\mathrm{P}}\right) * \mathrm{P}_{i} *\left(\frac{\mathrm{P}}{\mathrm{A}} / \frac{\mathrm{P}_{i}}{\mathrm{~A}_{i}}\right)\right) * 1 / \frac{\theta_{i}}{\theta}
\end{aligned}
$$

Where,

$\mathrm{N}_{R}=$ regional state total expenditure needs for the road sector;

$\mathrm{P}=$ the total population of the regional state;

$\mathrm{P}_{i}=$ the total population of the $i^{\text {th }}$ woreda;

$A=$ the total area of the regional state; and

$A_{i}=$ the total area of the $i^{\text {th }}$ woreda.

(vi) Calculate the expenditure need for the government administration $\operatorname{sector}(q=G)$

Variables used included population as a proxy and both land area and a proportion of urban population as disability factors.

Let $\mathrm{N}_{G i}$ denote the expenditure needed in the government administration sector for the $i^{\text {th }}$ woreda, and write:

$$
\mathrm{N}_{G i}=\left(\frac{\mathrm{N}_{G}}{\mathrm{P}_{G}}\right) * \mathrm{P}_{i} *\left[\left(\frac{n_{i}}{\mathrm{P}_{i}} / \frac{n}{\mathrm{P}}\right)\right] * 1 / \frac{\theta_{i}}{\theta}
$$

Using Equation (8), it can be written as:

$$
\mathrm{N}_{G i}=\left(\frac{\alpha_{G} \mathrm{~N}}{\mathrm{P}_{G}}\right) * \mathrm{P}_{i} *\left[\left(\frac{n_{i}}{\mathrm{P}_{i}} / \frac{n}{\mathrm{P}}\right)\right] * 1 / \frac{\theta_{i}}{\theta}
$$

Where,

$\mathrm{N}_{R}=$ regional state total expenditure needs for the

Government Administration Sector;

$\mathrm{P}=$ the total population of the regional state;

$\mathrm{P}_{i}=$ the total population of the $i^{\text {th }}$ woreda;

$n=$ the total urban population of the regional state;

$n_{i}=$ the average urban population in the $i^{\text {th }}$ woreda; and

$m=$ the total number of woredas in the regional state.

Finally, summing the results of Equations (10) to (22), we can write:

$\mathrm{N}=\mathrm{N}_{E i}+\mathrm{N}_{H i}+\mathrm{N}_{A i}+\mathrm{N}_{W i}+\mathrm{N}_{R i}+\mathrm{N}_{G i}$

Equation (23) says that the total expenditure needs of all sectors in a given woreda, is given by summing the expenditure needs of each individual sector.

\section{MODEL SIMULATION USING} DATA FROM TIGRAY: A CASE OF A REFORMING REGION
The proposed prototype formula attempted to iron out the anomalies and weaknesses of its precursors by introducing a model that considers both revenue capacity and expenditure needs of the woreda. In addition, it applied a unit cost in a much simpler and correct way. This model gained its prominence due to its ability to minimize the twin problem of vertical fiscal imbalances and horizontal fiscal imbalances.

\subsection{Estimating the Tigray Regional Transfer Pool}

The revenue sources for the Tigray state that form the basis for the available pool may be determined as follows:

$\mathrm{P}=\mathfrak{R}+\Gamma+\mathfrak{R}_{i}+\mathrm{Z}+\mathrm{Y}+\mathrm{A}$

Where,

$\mathrm{P}=$ total revenues available for Tigray BOFED;

$\Re=$ own source revenues collected at the regional level;

$\Gamma=$ transfers from the federal government;

$\mathfrak{R}_{i}=$ OSRs collected at the woreda level;

$\mathrm{Z}=$ loans;

$\mathrm{Y}=$ other income or revenues accrued to the region from public ownership of assets; and

$\mathrm{A}=$ aid from donors.

Tautologically, for instance, using 2006 data as provided, it can be observed that the region's pool summed up to $1,165.00$ million Birr. In consideration of the total transfer pool available, the regional BOFED allocated 530.00 million Birr to the woredas and the remaining 635.00 million Birr to the regional-level government, respectively. This implies that about 45 percent of the total regional pool was transferred to the woredas, while 55 percent was kept at the region level.

Notably, the analysis omitted the City of Mekele from the simulations since it was not entitled to receive transfers.

\subsection{Estimating Revenue Capacities}

In estimating the revenue capacity for the Tigray region (the rest of the reforming regions), the study used several woreda revenue sources:

First: The woreda's major taxes were estimated-i.e., a mean value of the woreda's major taxes that included rental income tax, combined agriculture and agricultural products taxes, agricultural income tax, individual profits tax, stamp duty taxes, and taxes on incomes and salaries. These were selected after ranking them in terms of their contribution to total tax revenues over the selected period.

The study ignored taxes that contributed less than approximately 2 percent of the total tax revenues. The aim was to estimate the revenue capacity of woredas by approximating revenue that could be raised in that woreda if the woreda governments taxed all the standard tax bases with the standard tax effort. Estimating the revenue capacity involved several steps, as shown in Table 1 below. 


\section{Business and Management Research (IJBMR)}

Research Article | Volume 9, Issue 1 | Pages 55-64 | e-ISSN: 2347-4696

\begin{tabular}{|c|c|c|c|c|}
\hline Type of tax & Rural Weredas & Urban Weredas & Total & \% Share \\
\hline Rental income & 1886860.85 & 128040 & 2014900.9 & 0.020 \\
\hline $\begin{array}{c}\text { Agriculture and } \\
\text { Agricultural Product }\end{array}$ & 645898.97 & 2449473.57 & 3095372.5 & 0.030 \\
\hline Agricultural income & 10427.5 & 5055998.1 & 5066425.6 & 0.050 \\
\hline Profits to individuals & 6590192.08 & 1806402.82 & 8396594.9 & 0.082 \\
\hline Stamp duty & 10293307.07 & 582409.81 & 10875717 & 0.106 \\
\hline Wages and salaries & 28836865.5 & 27386706.09 & 56223572 & 0.550 \\
\hline Total Tax Revenues & 59544185.94 & 42728624.32 & 102272810 & \\
\hline
\end{tabular}

Table 1: Major taxes for the Tigray region in the 2006 year.

Second: The study approximated the woreda's non-tax revenues. Another source of woreda revenues in Tigray were non-tax revenues, which consisted of various sources. Those were selected, which contributed largely to their category after ranking them by percentage share, as depicted in the Table 2 below. Only sources that contributed more than 1 percent qualified to be included in the analysis; examples included forestry products, medical examinations and treatments, veterinary services, hunting licenses, court fines, fines from government employees, road transport services, sales of medicines and medical supplies, and rural land use fees. Under this category, the analysis ignored revenues from charges for public assets; namely, royalty on public assets, since this category for woredas in Tigray does not contribute a significant amount of revenue.

\begin{tabular}{|c|c|c|c|c|}
\hline $\begin{array}{c}\text { Type of } \\
\text { non-tax } \\
\text { revenues } \\
\end{array}$ & $\begin{array}{c}\text { Rural } \\
\text { Weredas }\end{array}$ & $\begin{array}{c}\text { Urban } \\
\text { Weredas }\end{array}$ & Total & $\begin{array}{c}\% \\
\text { Share }\end{array}$ \\
\hline $\begin{array}{l}\text { Forestry } \\
\text { Products }\end{array}$ & 0 & 548097.3 & 548097.34 & 0.018 \\
\hline $\begin{array}{c}\text { Medical } \\
\text { examinations } \\
\& \text { treatments }\end{array}$ & 397769.2 & 873980.8 & 1271749.9 & 0.041 \\
\hline $\begin{array}{c}\text { Veterinary } \\
\text { services }\end{array}$ & 35933.56 & 1426283 & 1462217 & 0.047 \\
\hline $\begin{array}{l}\text { Hunting } \\
\text { license }\end{array}$ & 1637332 & 9094.15 & 1646426.3 & 0.053 \\
\hline Court fines & 546902.4 & 1393075 & 1939977.5 & 0.062 \\
\hline $\begin{array}{l}\text { Fines from } \\
\text { government } \\
\text { employees }\end{array}$ & 1209536 & 777864.2 & 1987400 & 0.064 \\
\hline $\begin{array}{c}\text { Road } \\
\text { transport } \\
\text { services }\end{array}$ & 2308705 & 252.19 & 2308956.9 & 0.074 \\
\hline $\begin{array}{c}\text { Sales of } \\
\text { medicines } \\
\text { and medical } \\
\text { supplies }\end{array}$ & 800261.6 & 4362216 & 5162477.9 & 0.166 \\
\hline $\begin{array}{l}\text { Rural land } \\
\text { use fee }\end{array}$ & 8062.62 & 9103794 & 9111856.6 & 0.293 \\
\hline $\begin{array}{c}\text { Total non- } \\
\text { tax revenues }\end{array}$ & 9225542 & 1893176 & 31118718 & \\
\hline
\end{tabular}

Table 2: Major non-tax revenues for the Tigray region in the 2006 year.

Third: The study chose the standard tax rates. In deriving the effective tax rate applicable to the proposed tax base, the arithmetic mean of a few selected woredas' effective tax rates was used, as depicted in Table (3) below in the last column. This was determined to be 1 percent.

\begin{tabular}{|c|c|c|}
\hline $\begin{array}{l}\text { Type of tax and } \\
\text { non-tax sources }\end{array}$ & $\begin{array}{c}\text { Potential Tax } \\
\text { Base }\end{array}$ & Effective Rate \\
\hline Rental income & $2,014,900.85$ & 0.02 \\
\hline $\begin{array}{l}\text { Agriculture and } \\
\text { Agriculture } \\
\text { Products }\end{array}$ & $3,095,372.54$ & 0.03 \\
\hline $\begin{array}{l}\text { Agricultural } \\
\text { income }\end{array}$ & $5,066,425.60$ & 0.05 \\
\hline $\begin{array}{l}\text { Profits to } \\
\text { individuals }\end{array}$ & $8,396,594.90$ & 0.08 \\
\hline Stamp duty & $10,875,716.88$ & 0.11 \\
\hline $\begin{array}{l}\text { Wages and } \\
\text { Salaries }\end{array}$ & $56,223,571.59$ & 0.55 \\
\hline Forestry Products & $548,097.34$ & 0.02 \\
\hline $\begin{array}{c}\text { Medical } \\
\text { examinations and } \\
\text { treatments }\end{array}$ & $1,271,749.93$ & 0.04 \\
\hline $\begin{array}{c}\text { Veterinary } \\
\text { services }\end{array}$ & $1,462,216.96$ & 0.05 \\
\hline Hunting license & $1,646,426.25$ & 0.05 \\
\hline Court fines & $1,939,977.50$ & 0.06 \\
\hline $\begin{array}{l}\text { Fines from } \\
\text { government } \\
\text { employees }\end{array}$ & $1,987,400.00$ & 0.06 \\
\hline $\begin{array}{l}\text { Road transport } \\
\text { services }\end{array}$ & $2,308,956.94$ & 0.07 \\
\hline $\begin{array}{c}\text { Sales of medicines } \\
\text { and medical } \\
\text { supplies }\end{array}$ & $5,162,477.85$ & 0.17 \\
\hline Rural land use fee & $9,111,856.64$ & 0.29 \\
\hline Total revenues & $111,111,741.77$ & 1.66 \\
\hline Mean & & 0.11 \\
\hline
\end{tabular}

Table 3: Potential tax and non-tax revenues as well as the effective tax rates for the Tigray region in the 2006 year.

Fourth: The study implemented the calculations via Equation (6) specified above to estimate the Tigray Woredas' revenue capacity. Ex post, the results were substituted into the grant formula.

\subsection{Estimating the Expenditure Needs}

Use Equation (7) to estimate the sectoral expenditures shares from the total woreda budget i.e., establish each sector's share 
as a percentage of total recurrent and capital budgets using 2006 data. Then use Equations (8) to (23) to estimate the pre-

determined six sectors' expenditure needs.

\begin{tabular}{|c|c|c|c|c|c|}
\hline $\begin{array}{c}\text { Sectoral } \\
\text { Shares }\end{array}$ & N & Minimum & Maximum & Mean & Std. Deviation \\
\hline$\alpha_{H}$ & 45 & 0.0370 & 0.2168 & 0.1026 & 0.0345 \\
\hline$\alpha_{E}$ & 45 & 0.1684 & 0.5452 & 0.3457 & 0.0841 \\
\hline$\alpha_{W}$ & 45 & 0.0000 & 0.0206 & 0.0076 & 0.0053 \\
\hline$\alpha_{R}$ & 45 & 0.0000 & 0.0109 & 0.0042 & 0.0031 \\
\hline$\alpha_{A}$ & 45 & 0.0000 & 0.2200 & 0.0864 & 0.0562 \\
\hline$\alpha_{G}$ & 45 & 0.1319 & 0.3211 & 0.1959 & 0.0459 \\
\hline $\begin{array}{c}\text { Capital Budget } \\
\text { Share }\end{array}$ & 45 & 0.0693 & 0.4593 & 0.2576 & 0.0705 \\
\hline $\begin{array}{c}\text { Recurrent } \\
\text { Budget Share }\end{array}$ & 45 & 0.5407 & 0.9307 & 0.7424 & 0.0705 \\
\hline
\end{tabular}

Table 4: Expenditure sectoral shares of key sectors.

\section{\& 7. RECOMMENDATIONS AND CONCLUSION}

The current article explored theoretical and empirical literature to design a unit cost methodology to establish an intergovernmental fiscal transfer formula for the FDRE. In achieving this objective, the study adopted three pragmatic approaches to research.

Firstly, it applied unit cost approach to the determination of the expenditure needs of the subnational levels of government. Secondly, it approximated revenue capacity by using a mix of representative tax systems on the national average. The derivation of fiscal gap followed from the two parameters obtained above; the study used these values to establish the total woreda entitlement and the total required resource or transfer pool at the regional level.

The prototype model was tested using data from the Tigray region in two steps. In the first stage, simulations were carried out to establish the total entitlements to each respective woreda in the region. Thereafter, econometric techniques were applied using ordinary least square (OLS) to evaluate the model performance.

In both, results turned out as expected, since the formulation proved to be highly equalizing. The foregoing results were the underpinning reason why the government adopted the formula as criteria to allocate grants from the regional level to the subnational levels of governments in 2007.

\section{ACKNOWLEDGEMENTS}

The research from this study was completed without funding or sponsorship. The author reports no conflicts of interest.

\section{REFERENCES}

[1] Lewis, B.D. (2002) Revenue - Sharing and Grant-Making in Indonesia: The First two Years of Fiscal Decentralization. In:
Smoke $\mathrm{P}$ (ed.) Intergovernmental Transfers in Asia, forthcoming, Manila: Asia Development Bank.

[2] Shirima, Ludovick L (2020) Rwanda: Lessons from Applied Intergovernmental Fiscal Equalization Formula. International Journal of Business and Management Research (IJBMR), 8 (4), 101-109.

[3] Bird, R.M., and Rodriguez, E. (1999) Decentralization and poverty alleviation. Public Administration and Development, 19, 199-219.

[4] Bird, R.M. (1998) Analysis of Earmarked Taxes. Tax Notes International, pp.2095-2116.

[5] Fujiwara, T. (1992) Intergovernmental Fiscal Relations in Japan. Draft, Eastern African Department, the World Bank.

[6] Bird, R.M. and Smart, M. (2002) Intergovernmental Fiscal Transfers: International Lessons for Developing Countries, World Development 30(6), pp. 899-912.

[7] Broadway, R.W. and Hobson P.A.R, (1993) Intergovernmental Fiscal Relations in Canada. Canadian tax Foundation, Canadian Tax Paper No. 96.

[8] Smart, M. (1998) Taxation and deadweight loss in a system of intergovernmental transfers. Canadian Journal of Economics, 31, 189-206.

[9] Baretti, C., Huber, B., and Lichtblau, K. (2000) A tax on tax revenue. The incentive effects of equalizing transfers: evidence from Germany. Working Paper CESifo, University of Munich.

[10] Musgrave, R. (1993) Who should tax, Where and What? In: McLure, Jr. C (ed.), Tax Assignment in Federal Countries. Canberra: Centre for Research on Federal Financial Relations, ANU.

[11] Rye, R.C. and Searle B. (1996) The Fiscal Transfer System in Australia. In: ahmad A (ed.) Intergovernmental Fiscal Transfer (forthcoming), Washington, D.C.: International Monetary Fund.

[12] Bird, R.M. (1986) Federal finance in comparative perspective. Toronto: Canadian Tax Foundation.

[13] Shah, A. (1994a) The Reform of Intergovernmental Fiscal Relations in Developing and Emerging Market Economies. Policy and Research Series No.23, Washington, D.C.: World Bank. 
[14] Shah, A. (1994b) Intergovernmental Fiscal Relations in Indonesia: Issues and Reform Options, Discussion Paper No.239, Washington, D.C.: World Bank.

[15] Brodjonegoro, B. and Martinez-Vazquez, J. (2002) An Analysis of Indonesia's Transfer System: Recent Performance and Future Prospects. Conference on Can Decentralization Help Rebuild Indonesia? Andrew Young School of Policy Studies, George State University, Atlanta.

[16] Bird, R.M. (2000) Rethinking subnational taxes: a new look at tax assignment. Tax Notes International, 20, 2069-2096.

[17] Chernick, H. (2000) Federal grants and social welfare spending: do state responses matter. National Tax Journal, 53, 143-152.

[18] Bird, R.M. and Wallich, C. (1993) Fiscal Decentralization and Intergovernmental Relations in Transition Economies. World Bank Working Paper WPS1122.

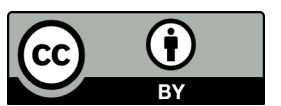

(C) 2020 by the Dr. Ludovick Leon Shirima. Submitted for possible open access publication under the terms and conditions of the Creative Commons Attribution (CC BY) license (http://creativecommons.org/licenses/by/4.0/). 